\title{
Non-small cell lung cancer - genetic predictors
}

\author{
Vladimira Koudelakova, Magdalena Kneblova, Radek Trojanec, Jiri Drabek, Marian Hajduch
}

\begin{abstract}
Background. Non-small cell lung cancer (NSCLC) accounts for approximately $85 \%$ of all lung cancer that is the leading cause of cancer-related mortality worldwide. Several predictive markers have been found in NSCLC patients to date but only a few are currently used for tailored therapy.

Methods and Results. PubMed and Web of Science online databases were used to search review and original articles on the most important predictive markers in NSCLC.

Conclusion. EGFR activating mutations (exons 18 to 21) and EML4-ALK rearrangement are clinically important markers able to select NSCLC patients which benefit from EGFR or ALK tyrosine kinase inhibitors (gefitinib, erlotinib, crizotinib). Other markers, such as KRAS mutation, EGFR T790M mutation and C-MET amplification, are responsible for resistance to these inhibitors. Overcoming of this resistance as well as discovery of new potential markers and inhibitors is the main goal of ongoing research and clinical trials in NSCLC.
\end{abstract}

Key words: NSCLC, EGFR, KRAS, ALK, C-MET, ROS1, tyrosine kinase inhibitors, resistance

Received: December 7, 2012; Accepted with revision: April 25, 2013; Available online: May 29, 2013 http://dx.doi.org/10.5507/bp.2013.034

Laboratory of Experimental Medicine, Institute of Molecular and Translational Medicine, Faculty of Medicine and Dentistry, Palacky University Olomouc and University Hospital Olomouc, Czech Republic

Corresponding author: Vladimira Koudelakova, e-mail: koudelakovav@gmail.com

\section{INTRODUCTION}

Lung cancer is the most frequent cause of cancer-related deaths worldwide and it is responsible for more than 1 million deaths annually ${ }^{1,2}$. The main reason is high tumor aggressivity and high metastasis potential. Non-small cell lung cancer (NSCLC) is diagnosed in approximately $85 \%$ of lung cancer cases and includes the adenocarcinoma, squamous cell carcinoma and large cell carcinoma subtypes $^{3}$. The intensive research has been made in the past few years on genetic, transcriptional, translational and epigenetic levels and the remarkable discoveries have been found. At least nine important driver mutations causing NSCLC have been described, mainly in adenocarcinoma subtype. Several markers are already used for best treatment strategy selection. Developing new drugs targeting the markers, clarification of predictive value of these markers as well as new markers discovering is still the subject of intensive research ${ }^{4}$. In this review, the clinically most important genetic alterations in NSCLC, such as EGFR, KRAS, C-MET, EML4-ALK and ROS1 are summarized.

\section{EGFR}

The epidermal growth factor receptor (EGFR) gene is located on $7 \mathrm{p} 11$ and encodes a tyrosine-kinase receptor from the HER family which is involved in development, progression, angiogenesis and metastasis of various cancer types. After ligand binding (EGF, TGF- $\alpha$, amphiregulin), the receptor hetero-/homodimerizes, autophosphorylates tyrosine residues and activates two main downstream signaling pathways - RAS/MAPK and PI3K/ AKT $\left(\right.$ ref. $^{5}$ ). Three mechanisms of EGFR activation in tumor cells have been described, including EGFR mutations, amplification/gene copy number gain $(\mathrm{CNG})$ and overexpression.

\section{Amplification/overexpression}

EGFR overexpression is found in up to $80 \%$ of NSCLC cases and EGFR CNG/amplification is found in almost $60 \%$ of them, while these events often occur concurrently ${ }^{6-12}$. Increased EGFR expression was considered to be a poor prognostic factor in NSCLC patients ${ }^{12,13}$ but a meta-analysis combining 18 studies of 2972 patients did not confirm the prognostic significance of EGFR expression $(\mathrm{HR}=1.14 ; 95 \% \mathrm{CI} 0.97-1.34 ; P=0.103)\left(\right.$ ref. $\left.^{14}\right)$.

The predictive value of EGFR amplification/overexpression for responsiveness to EGFR tyrosine kinase inhibitors (EGFR TKIs) was tested in several studies. Initial studies, including the large trials BR.21 and ISEL, found clear association between increased EGFR copy number and good response to EGFR TKIs(ref., ${ }^{9-17}$ ). Other studies have not confirmed this finding ${ }^{18,19}$. In a recent meta-analysis ${ }^{20}$ which combined 22 independent studies (2005-2009) including 1821 NSCLC patients treated with EGFR TKIs monotherapy, EGFR CNG was significantly associated with increased overall survival $(\mathrm{OS})(\mathrm{HR}=0.77$; 95\% CI 0.66-0.89; $P=0.001)$, progression-free survival (PFS) $(\mathrm{HR}=0.60 ; 95 \%$ CI 0.46-0.79; $P<0.001)$ and time-toprogression (TTP) $(\mathrm{HR}=0.50 ; 95 \% \mathrm{CI} 0.28-0.91 ; P=0.02)$. The following studies published by Brugger et al. ${ }^{21}$ and Hirsch et al. ${ }^{22}$ did not confirm the predictive significance of EGFR FISH positivity to erlotinib. The clinical relevance of EGFR amplifications is difficult to decipher 
because about $50 \%$ of EGFR-mutated cases show the coexistence of increased EGFR copy number. The predictive value of EGFR copy number could be therefore affected by the occurrence of simultaneous EGFR mutation ${ }^{8,15,23}$. At the present, EGFR copy number testing is not recommended in the selection of treatment in NSCLC.

\section{Activating mutations}

In 2004, two independent research groups ${ }^{24,25}$ sequenced EGFR in advanced NSCLC patient samples. The aim was to evaluate the possible predictive value of EGFR mutations for EGFR TKIs therapy. In 14 out of 15 patients who were good responders to gefitinib therapy, small in-frame deletions or amino acid substitutions were identified. No EGFR mutations were found in gefitinib non-responders. In these studies, EGFR activating mutations were identified ${ }^{24,25}$.

Activating mutations of EGFR, occurring in exon 18 to 21 in the ATP-binding pocket part of the tyrosine-kinase domain, have been reported in 5 to $30 \%$ NSCLC cases depending on study population (app. 15\% incidence in Caucasians compared to $30 \%$ in Asians). These mutations lead to a ligand-independent EGFR activation and are preferentially found in never/former smokers, women, East Asians and patients with adenocarcinoma histology. More than 3000 somatic EGFR mutations have been described to date ${ }^{26}$. Deletions in exon 19 (including residues 746 to 753 ) and arginine to leucine substitution (L858R) in exon 21 constitute about $90 \%$ of them ${ }^{6,8,27}$. Substitution of glycine to serine, alanine or cysteine in codon 719 (G719X) of exon 18 occurs in an additional 4\% of cases and other missense mutations and small in-frame duplications/insertions in exon 20 account for the rest ${ }^{6}$.

\section{Targeted therapy}

The most effective inhibitors of EGFR tyrosine kinase signalization are the small anilinoquinazoline derivatives, that act as reversible ATP-competitive inhibitors, erlotinib (Tarceva ${ }^{\circledR}$, Genentech) and gefitinib (Iressa ${ }^{\circledR}$, AstraZeneca).

After successful preclinical ${ }^{28}$ and phase I clinical studies $^{29,30}$, gefitinib progressed to phase II studies. Objective response rates between 10 and $20 \%$ were reported in two double-blind, randomized phase II trials (IDEAL 1 and 2) which enrolled 210 and 221 NSCLC patients previously treated with one or two regimes ${ }^{31,32}$. Based on these results, gefitinib was FDA approved for advanced NSCLC patient treatment in May 2003. Based on results from unsuccessful ISEL study, in June 2005, FDA limited the use of gefitinib. However, the IPASS trial confirmed the benefit of patients with EGFR mutations of gefitinib therapy and European Medicines Agency (EMA) approved gefitinib for the treatment of locally advanced or metastatic NSCLC patients with EGFR activating mutation in June 2009 (ref. $^{33,34}$ ).

The low-molecular weight inhibitor, erlotinib, showed antitumor activity in preclinical and phase I clinical studies $^{35}$. Erlotinib was FDA approved in November 2004 based on the results of phase III randomized trial BR.21 which included 731 NSCLC patients treated by erlotinib or placebo in second or third line setting. The OS of the treated group was 2 months longer than the placebo group (6.7 months vs. 4.7 months). The 1 -year OS was $31 \%$ for the erlotinib group compared to $22 \%$ for the control group $^{36}$

The predictive role of EGFR mutations to EGFR TKIs therapy sensitivity was revealed by different studies and confirmed by large meta-analysis including 59 studies of 3101 NSCLC patients. EGFR mutations were predictive of response to single agent EGFR TKIs with sensitivity and specificity of 0.78 , resp. 0.86 (ref. ${ }^{37}$ ). Many other studies elucidating EGFR TKIs efficiency in different settings and biomarker-selected populations were recently reviewed ${ }^{38,39}$. In general, EGFR TKIs treatment significantly improves the survival of NSCLC patients with EGFR mutations compared to chemotherapy.

Several clinical trials, clearly reviewed by Patil et al. ${ }^{40}$, are evaluating the efficacy of cetuximab (Erbitux ${ }^{\circledR}$, Merck $\mathrm{KGaA}$ ) in combination with various types of treatment and assessing the predictive role of EGFR, KRAS and other potential biomarkers. Predictive value of EGFR mutations, amplification or overexpression and KRAS mutations for cetuximab therapy was not confirmed to date ${ }^{41,42}$.

\section{EGFR TKIs and de novo resistance}

The best described mechanism of de novo resistance to EGFR TKIs is mutation in the KRAS oncogene which is present in 20 to $30 \%$ of lung cancer patients. KRAS and its importance for NSCLC therapy management is discussed below. Another cause of de novo resistance is the occurrence of insertion mutations in exon 20 of EGFR. In vitro studies have demonstrated that insertion in EGFR exon 20 causes both oncogenic transformation and resistance to EGFR TKIs (ref. ${ }^{43}$ ). Experiences with patients harboring EGFR exon 20 insertions corresponds with preclinical data. Clinical data showed very few responses to EGFR TKIs in these patients ${ }^{15,44,45}$. Substitution of methionine to threonin at position 790 (T790M) of the EGFR exon 20 was reported in $2.7-40 \%$ of TKI-naïve cas$\mathrm{es}^{44,46,47}$. Patients with this mutation were found to have poorer outcome on EGFR TKIs therapy ${ }^{47-49}$. A secondary T790M mutation is more frequent and is associated with acquired resistance (described below). De novo resistance to EGFR TKIs therapy was also found in NSCLC patients with HER2 exon 20 insertions. Cancer cells presenting this mutation remain sensitive to HER2 targeted therapies but show resistance to EGFR TKIs (ref. ${ }^{50,51}$ ).

\section{TKIs and acquired resistance}

Acquired resistance to EGFR TKIs is a serious problem because the majority of initially responsive, EGFR TKIs-treated patients develop resistance within 12 months ${ }^{52}$. Resistance to EGFR TKIs may be caused by presence of cancer stem cell-like cells which are selected during EGFR TKIs therapy ${ }^{53}$. Generally, two crucial mechanisms of acquired resistance have been described, secondary T790M EGFR mutation and C-MET amplification. T790M mutation was described as the first mechanism of EGFR TKIs acquired resistance in 2005 by Kobayashi and Pao et al. ${ }^{54,55}$. Both groups studied NSCLC 
patients with EGFR activating mutation (L858R or exon 19 deletion), who progressed on the gefitinib or erlotinib therapy. The T790M mutation was identified by comparison of pre- and post-progression samples and confirmed on NSCLC cell lines in vitro. A secondary T790M mutation is localized in the ATP-binding pocket of the kinase domain and is present in approximately $50 \%$ of NSCLC patients with acquired resistance ${ }^{27,56-58}$. Substitution in codon 790 increases ATP binding affinity of EGFR tyrosine kinase domain and EGFR TKIs are not able to bind. T790M mutated cells lose sensitivity to gefitinib and erlotinib but not to irreversible TKIs (e.g. pan-HER inhibitor PF0299804) (ref. $\left.{ }^{59}\right)$. A second mechanism of acquired resistance, C-MET amplification, is discussed below.

\section{KRAS}

KRAS (Kirsten rat sarcoma viral oncogene homo$\log$ ) gene localized on $12 \mathrm{p} 12$ encodes membrane-bound GTPase protein which, as well as other members of the RAS protein family (NRAS and HRAS), plays an important role in EGFR-mediated signal transduction. EGFR activates KRAS through the adaptor protein Grb2 (growth factor receptor-bound protein 2) and guanine nucleotide-exchange factor (GEF) molecules which are responsible for exchange of GDP to GTP. GTP-KRAS binds target proteins (e.g. RAF), activates them and GTPase activating proteins (GAP) stimulate GTP hydrolysis. KRASmediated signaling regulates several cellular processes, such as proliferation, differentiation and survival.

\section{Activating mutations}

Pathologic KRAS activation resulting from mutations in the KRAS gene has been found in many cancer types including NSCLC. KRAS mutations occur in approximately $20 \%$ of lung cancer cases ${ }^{60,61}$. The majority (about $90 \%$ ) of found point mutations occur in exon 2 (codon 12 and 13), less frequent are mutations in exon 13 (codon 61) (ref. ${ }^{26,61}$ ). Point mutation leads to amino acid substitution and GAP insensitivity resulting in constitutively active GTP-binding KRAS signal transduction. KRAS mutations are more frequently found in Caucasian population, adenocarcinomas, males and current smokers ${ }^{60,62,63}$. In never smoking patients with adenocarcinoma, KRAS mutation is probably associated with transition mutation ( $G$ to $A$ ) compared to transversion ( $\mathrm{G}$ to $\mathrm{T}$ or $\mathrm{G}$ to $\mathrm{C}$ ) in current smokers $^{60}$. Recent meta-analysis has shown KRAS mutations occurring in $26 \%$ of former or current smokers vs. $6 \%$ in never smokers ${ }^{64}$. The majority of studies have shown that KRAS and EGFR mutations are mutually exclusive $^{63,65-68}$. Co-existence of both mutations was reported by Han et al. only ${ }^{69}$.

\section{Prognostic role}

Several studies have evaluated the importance of KRAS mutations for survival, recurrence and metastasis. In 2005, Mascaux et al. ${ }^{70}$ published the results of metaanalysis comparing KRAS prognostic significance in 28 independent retrospective studies with a total number of 3620 patients included. This meta-analysis showed a worse survival of KRAS mutated patients with HRs of 1.30 (95\% CI, 1.20-1.49; $P=0.01$ ). In subgroup analysis, KRAS was a statistically significant prognostic factor in adenocarcinomas $(\mathrm{HR}=1.52 ; 95 \% \mathrm{CI}, 1.30$ to 1.78 ; $P=0.02$ ) but not in squamous cell carcinomas. Following studies did not confirm KRAS mutations as an independent prognostic factor ${ }^{67,68}$. The prognostic importance of KRAS mutations in NSCLC remains controversial and needs to be confirmed on prospective well-defined NSCLC patient cohorts.

\section{Resistance to EGFR TKIs}

Although the prognostic role of KRAS mutations is not clearly described, the predictive significance of EGFR TKIs therapy response was confirmed in several studies. KRAS mutations have been reported to be associated with de novo resistance to EGFR inhibitors in NSCLC patients in several studies ${ }^{15,16,19,58,65,69}$. Recently Mao et al. published meta-analysis of 22 studies analyzing 1470 NSCLC patients, KRAS mutation was detected in 16\% (231/1470). Objective response rate (ORR) of KRAS mutated patients was $3 \%$ compared to $26 \%$ ORR in patients with wt-KRAS. This analysis confirmed that KRAS mutations are negative predictors of tumor responsiveness to EGFR TKIs therapy in NSCLC (ref. ${ }^{64}$ ). However, due to the mutual exclusivity of EGFR and KRAS mutations, the clinical importance of KRAS assessment in NSCLC remains low.

\section{C-MET}

The C-MET protooncogene is localized on chromosome region $7 \mathrm{q} 31$ (ref. ${ }^{71}$ ) and codes a tyrosine kinase receptor - hepatocyte growth factor receptor (HGFR). $\mathrm{HGF} / \mathrm{SF}$ (hepatocyte growth factor/ scatter factor) is the only known ligand of this receptor. HGF binding results in phoshorylation of C-MET tyrosine residues ${ }^{72}$, recruitment of adaptor proteins Grb2, Gab1, SHC and activation of downstream MAPK, PI3K-Akt and STAT signaling pathways ${ }^{73-75}$. C-MET and HGF are required for normal tissue development and therefore they are widely expressed in a various cell types. C-MET/HGF dysregulation and pathogenic activation is described in almost all cancer types ${ }^{76-78}$ and has been identified as a promising therapeutic target. The first reported oncogenic C-MET activation resulting from translocation of chromosome 1 and 7 was found in an osteosarcoma cell line. Fusion TRP-MET protein has constitutive tyrosine kinase transforming activity ${ }^{76}$. C-MET can be activated by many other mechanisms, such as amplification, overexpression of receptor or ligand and point mutation ${ }^{57,79,80}$.

\section{Amplification/overexpression}

C-MET amplification leads to receptor overexpression and constitutive HGF-independent activation ${ }^{81}$. C-MET amplification has been reported in range from 3 to $21 \%$ of EGFR TKI-naïve NSCLC patients and is associated with poor prognosis, increased proliferation, tumor invasiveness and angiogenesis ${ }^{82-87}$. The greatest percentage of 
reported C-MET FISH-positive cases results from chromosome 7 polysomy. True C-MET amplification is rare event in NSCLC, occurs in 3 to $7 \%$ cases $^{84-86,88,89}$. Some studies have reported association between C-MET and EGFR amplification ${ }^{83,84}$. Chromosome 7 polysomy is probably responsible for significant correlation between EGFR and C-MET FISH positivity. Higher copy number/ overexpression of C-MET was found in brain metastasis compared to primary lung tumor tissues. C-MET-activated tumor cells have probably higher potential to migrate and create metastasis $^{90,91}$.

\section{Resistance to EGFR TKIs}

The importance of C-MET copy number evaluation rapidly increased when Engelman et al. found that the cause of acquired resistance to gefitinib in an NSCLC cell line (HCC827) is amplification of chromosomal region 7q31.1-7q33.3 where C-MET is localized. Consequently, C-MET-driven EGFR TKIs resistance was confirmed on 18 NSCLC patient samples ${ }^{57}$. C-MET amplification has been described in approximately $20 \%$ of NSCLC patients with acquired resistance ${ }^{57,88,92-94}$; in some cases T790M mutation of EGFR occurs simultaneously. Engelman et al. found that the bypass mechanism of C-MET signaling activation in resistant cells is through ERBB3-mediated PI3K-Akt signaling pathway ${ }^{57}$.

Turke et al. theorized that NSCLC cells become C-MET amplified and therefore resistant during EGFR TKIs treatment by selection of a preexisting small C-MET amplified clone ${ }^{95}$. This study was performed on EGFR TKIs-sensitive NSCLC cell line HCC827 and 27 paired NSCLC patient samples (pre- and post-therapy). In the cell line study, a small subpopulation of C-MET amplified cells increased 300x over 19-days EGFR TKIs exposure. In tumor samples, C-MET-driven resistance was observed in 4 out of 27 cases, rare subpopulation $(<1 \%)$ of C-MET amplified cells was found in pre-treatment specimens in all 4 cases. These data suggest that acquired C-METdriven resistance can be suppressed by dual EGFR and C-MET inhibition.

\section{Targeted therapy}

Several strategies of C-MET inhibition based on the mechanism of $\mathrm{HGF} / \mathrm{C}-\mathrm{MET}$ activation have been reported. In C-MET amplified/overexpressed tumors, selective blockade of active receptor by small-molecule inhibitors or monoclonal antibodies seem to be effective. Several C-MET TKIs such as PHA665752 (ref. ${ }^{81,96}$ ), PF-02341066 (crizotinib, Xalkori ${ }^{\circledR}$, Pfizer), SGX523 (ref. ${ }^{97,98}$ ), ARQ197 (tivantinib, ArQule) (ref. ${ }^{99,100}$ ) and XL184 (cabozantinib, Exelixis) (ref. ${ }^{101}$ ) as well as monoclonal antibody MetMAb (onartuzumab, Genentech) (ref. ${ }^{102}$ ) were tested in a preclinical setting on NSCLC cell lines and xenograft models.

Cabozantinib, dual inhibitor of VEGFR2 and C-MET, has reached clinical testing in several cancer types. In NSCLC, cabozantinib is investigated in combination with erlotinib compared to erlotinib alone in phase I/II clinical study (NCT00596648) (ref. ${ }^{103}$ ). This inhibitor seems to be an effective inhibitor of tumor angiogenesis and metastasis in C-MET-deregulated NSCLC cases ${ }^{101}$.

One of the most promising molecules is the non-ATPcompetitive selective C-MET inhibitor tivantinib which passed phase I and II clinical trials. Sequist et al. ${ }^{104}$ reported results of double-blind randomized phase II trial (NCT00777309) including 167 randomly assigned previously treated, EGFR TKI-naïve NSCLC patients. Patients who obtained erlotinib combined with tivantinib (ET) were compared to patients obtaining erlotinib with placebo (EP). Median PFS was 3.8 months for ET compared to 2.3 months for $\mathrm{EP}(\mathrm{HR}=0.81$; $95 \% \mathrm{CI}, 0.57-1.16$; $P=0.24)$. ET-treated patients had significantly longer time to development of new metastasis (7.3 vs. 3.6 months, $P<0.01)$. Significantly better response to ET therapy was observed in KRAS mutated patients compared to KRAS mutated in the EP regime $(\mathrm{HR}=0.18 ; 95 \% \mathrm{CI}, 0.05$ to 0.70 ; $P=0.006)$. In this study, only 2 patients had true C-MET amplification, increased copy number ( $\geq 4$ copies/cell) was found in 37 patients. C-MET positive patients tend to benefit from the ET regime and this benefit rises with increasing cut-off of C-MET copy number. Tivantinib in combination with erlotinib can prolong PFS, OS and time to metastasis in NSCLC patients compared to erlotinib alone. Ongoing clinical trials combining tivantinib and erlotinib in different setting are summarized in Table 1.

Crizotinib, a dual inhibitor of ALK and C-MET kinases is approved for treatment of NSCLC patients with ALK rearrangement. Nevertheless, response to crizotinib was shown in non-ALK rearranged NSCLC cell lines, xenograft model ${ }^{105}$ as well as patient with de novo amplification of C-MET ( ref. $^{106}$ ). Anti-tumor activity of crizotinib is studied in randomized phase I/II trial (NCT00965731) in NSCLC patients treated by erlotinib alone versus erlotinib in combination with crizotinib ${ }^{103}$. The results from this study could clarify the inhibitory effect of crizotinib in C-MET amplified cases as it was shown on xenograft models ${ }^{107}$.

MetMAb (onartuzumab) in combination with erlotinib have been evaluted in randomized, double-blind, phase II trial (NCT00854308). PFS was 2.2 vs. 2.6 months for patients obtained erlotinib + MetMAb (EM) vs. erlotinib + placebo (EP). In subgroup of C-MET positive NSCLC patients, PFS was 2.9 for EM vs. 1.5 months for EP. Efficiency of MetMAb in NSCLC should be confirmed by ongoing clinical trials combining MetMAb with erlotinib (NCT01456325), bevacizumab/ pemetrexed (NCT01496742) and paclitaxel + platinum (NCT01519804) (ref. $\left.{ }^{103}\right)$.

\section{ALK}

The ALK (anaplastic lymphoma kinase) protein is a transmembrane tyrosine kinase receptor normally expressed only in the small intestine, testis and brain ${ }^{108}$ but not in normal lung tissue ${ }^{109}$. Translocation of the ALK gene $t(2 ; 5)$ leading to NPM1-ALK fusion was firstly reported by Morris et al. ${ }^{108}$ in anaplastic large cell lym- 


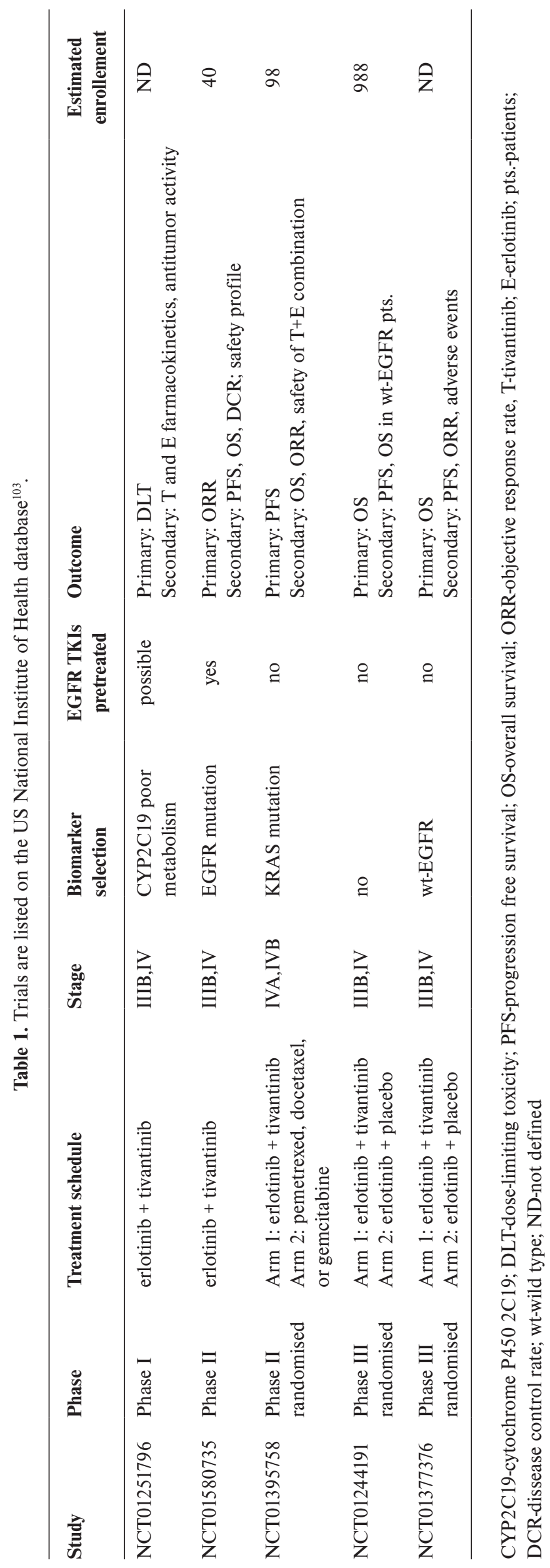


phoma (ALCL). Alterations of ALK gene were also identified in neuroblastomas ${ }^{110}$ and inflammatory myofibroblastic tumors ${ }^{111}$. In 2007, Soda and colleagues identified a small inversion in the short arm of chromosome 2, inv(2)(p21p23) in NSCLC patients. This inversion leads to fusion of the N-terminal part of the echinoderm microtubule associated protein like-4 (EML4) with kinase domain of ALK (ref. ${ }^{112}$ ).

\section{EML4-ALK fusion}

EML4-ALK rearrangement is being found in approximately $2-7 \%$ NSCLC cases ${ }^{113-115}$. The fusion leads to protein redistribution to cytoplasm ${ }^{112}$ and protein dimerization via coiled-coil domains of EML4 resulting in phosphorylation and highly oncogenic ALK kinase activation $^{116,117}$. More than 13 variants of EML4-ALK have been identified to date containing different parts of EML4; the coiled-coil domain is preserved in all variants. Exon 13 (variant 1 ), resp. exon $6 \mathrm{a} / \mathrm{b}$ (variant $3 \mathrm{a} / \mathrm{b}$ ) of EML4 fused to the ALK exon 20 are the two most frequent variants which are present in more than $50 \%$ cases $^{117-120}$. Tree other rare fusion partners of ALK are known in NSCLC, KIF5B (ref. ${ }^{121}$ ), TFG (ref. ${ }^{122}$ ) and KLC1 (ref. ${ }^{123}$ ). The incidence of these fusion partners is less than $1 \%$ (ref. ${ }^{121,122,124}$ ). Heuckemann et al. showed that protein stability and sensitivity to treatment depend on EML4-ALK variant and fusion partner type ${ }^{125}$.

Except for ALK rearrangement, ALK amplification/ CNG have been reported ${ }^{120,126}$. Increased ALK copy number was associated with EGFR FISH positivity but no association with prognosis was found ${ }^{126}$. The significance, if any, of ALK CNG for response to therapy, prognosis or histopathologic features, needs to be analyzed.

A subgroup of EML4-ALK patients has typical clinical and histological features. ALK rearrangement is typically found in adenocarcinoma with signet ring cell subtype, younger patients ${ }^{113,114,116,117}$ with never or light (10 packs per year) smoking history ${ }^{114,127}$. No other association with gender or ethnicity has been found. ALK fusion is mutually exclusive in most NSCLC cases ${ }^{114,128,129}$, concurrent EGFR and KRAS mutations were described in only few cases $^{130-134}$.

\section{Targeted therapy}

EML4-ALK fusion is a therapeutic target for the ATPcompetitive TKI crizotinib. In preclinical analyses, the inhibitory effect of crizotinib was confirmed on ALK rearranged cell lines derived from a variety of human cancers $^{135,136}$. Based on these studies, crizotinib entered multicenter, open-label phase I trial (NCT00585195). In this study, crizotinib showed significant antitumor activity in enrolled 82 advanced, ALK-positive NSCLC patients. The ORR to crizotinib was $57 \%$ at mean treatment duration of 6.4 months. The estimated probability of 6 month progression-free survival was $74 \%$ (ref. ${ }^{113}$ ). In the retrospective data analysis from this study, reported by Shaw et al. ${ }^{115}$, the 1 -year OS was $74 \%$ and 2 -year OS was $54 \%$. ALK-positive patients treated by crizotonib had similar OS compared to EGFR TKIs-treated EGFR- mutant patients $(P=0.786)$ but significantly better OS than ALK-positive crizotinib-untreated group. Moreover, ALKpositive crizotinib-treated patients had significantly better OS $(P=0.020)$ than controls (wt-EGFR, ALK-negative) treated by conventional chemotherapy. Based on the results of phase I study and ongoing phase II studies (255 patients; NCT00932451), crizotinib (Xalkori®, Phizer) was FDA approved in August 2011 and EMA approved in October 2012 for treatment of locally advanced or metastatic ALK-positive NSCLC patients. Ongoing clinical trials evaluating efficiency of crizotinib in different setting are summarized in Table 2.

\section{Resistance to crizotinib}

Similar to other TKIs therapies, de novo as well as acquired resistance to crizotinib have already been reported. Two mutations in ALK kinase domain, C1156Y and L1196M, were identified as potential mechanisms of resistance to crizotinib therapy in 28-years old NSCLC patient ${ }^{137}$. Both mutations as cause of acquired resistance to crizotinib were confirmed in following studies ${ }^{134,138}$ and other resistance-related mutations, L1152R, G1269A/S and S1206R, have been described ${ }^{134,139,140}$. Some other potential mechanisms of resistance, such as EML4-ALK CNG, KRAS and EGFR concurrent mutations, were described by Doebele et al. ${ }^{134}$.

Several treatment strategies overcoming crizotinib resistance are tested on cell lines and xenografts models ${ }^{141,142}$. The Hsp90 inhibitors which show the most promising results are tested in number of clinical trials. Inhibitors IPI-504 (Phase II; NCT01228435), AP26113 (Phase I/II; NCT01449461), CH5424802 (Phase I/II; NCT01588028), X396 (Phase I; NCT01625234) are tested in advanced lung cancer patients in monotherapy ${ }^{125,143}$ whereas STA9090 (Phase I/II; NCT01579994) and AT13387 (Phase I/II; NCT01712217) inhibitors are tested in combination with crizotinib (detailed in Table 2) (ref. ${ }^{103}$ ).

\section{OTHER CLINICALLY IMPORTANT BIOMARKERS}

HER-2 (17q) overexpression has been described in approximately $20 \%$ NSCLC cases, whereas insertion in HER-2 exon 20 is the rare event (2\%). These mutations occur mainly in adenocarcinoma, non-smokers and Asians and are associated with resistance to EGFR TKIs (ref. ${ }^{50}$ ). This resistance can be overcome by dual TKIs inhibition by lapatinib or BIBW 2292 (ref. ${ }^{51,144}$ ).

Translocation of ROS1 gene (6q) was identified as potential driver mutation in NSCLC cell lines ${ }^{122}$. ROS1 gene rearrangement has been described in approximately $2 \%$ NSCLC cases and tree fusion partners, CD74, SLC34A2 and FIG, have been identified to date ${ }^{145,146}$. Patients with ROS1 rearrangement have similar features as patients harboring EGFR mutation or ALK rearrangement, ROS1 rearranged patients are more likely Asian, younger and never smokers with adenocarcinoma histology ${ }^{145}$. ROS1 rearrangement leads to constitutive kinase activity and sensitivity to TKIs in vitro ${ }^{135}$. Bergethon et al. 


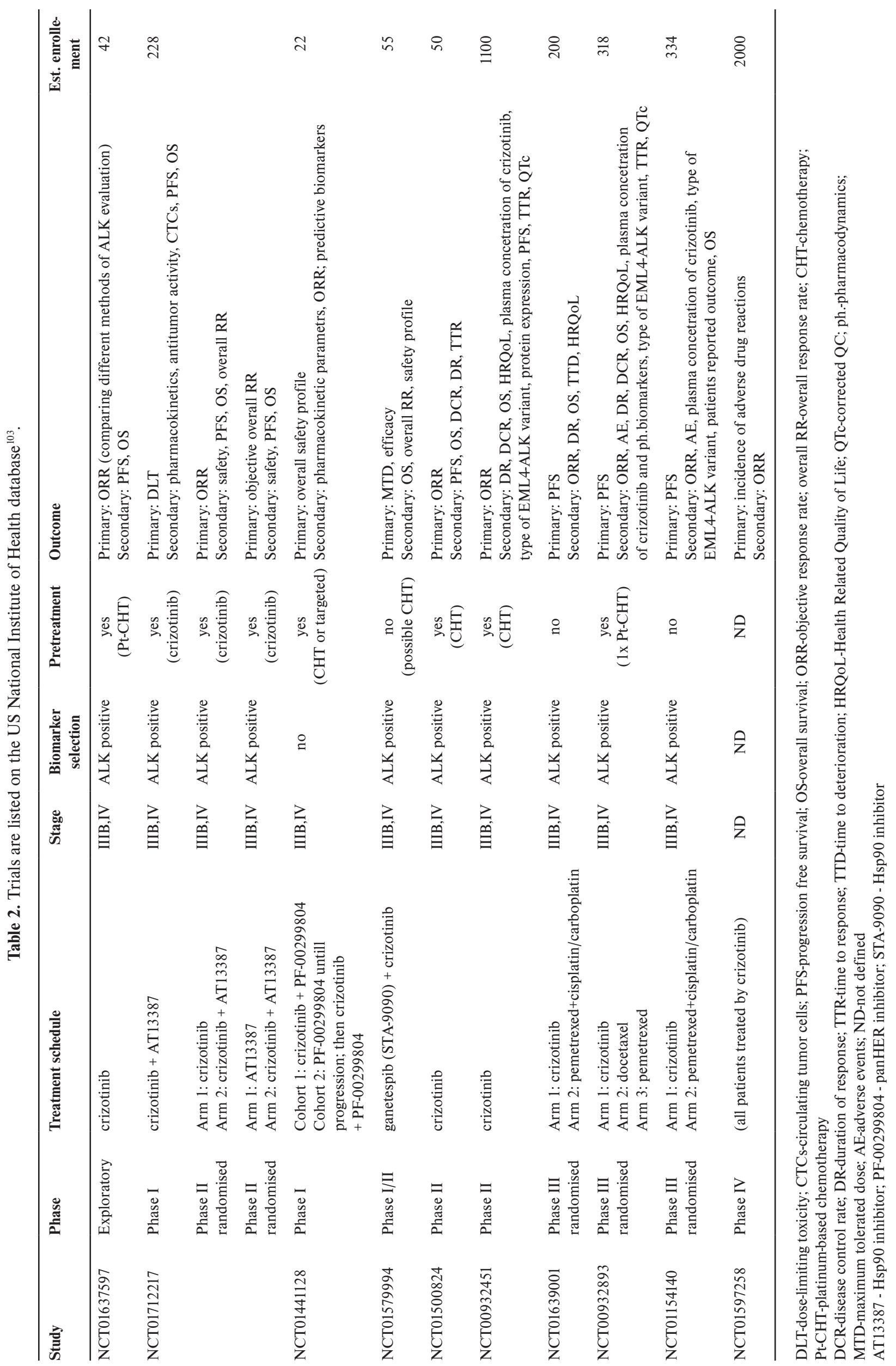


showed promising antitumor activity of crizotinib in one patient with ROS1 rearrangement treated in clinical trial NCT00585195 (ref. ${ }^{145}$ ).

Mutations in PIK3CA, BRAF and AKT genes were reported in up to $3 \%$ of lung cancer cases. Large scale of BRAF, MEK, AKT and mTOR inhibitors are tested in ongoing clinical trials and are a promise for new personalized treatment opportunities in NSCLC patients ${ }^{147,148}$.

\section{CONCLUSION}

Personalized medicine requires molecular genetic testing prior to decision about which therapeutic regimen is appropriate for an individual patient. Several predictive markers have been identified in NSCLC patients but only the minority of them is clinically used for therapy individualization. Nevertheless, personalized therapeutic opportunities of NSCLC are expected to increase in the following years. Number of clinical trials is currently evaluating efficiency of inhibitors directed against various genetic markers and ongoing intensive research is focused on identification of new therapeutic targets as well as testing new therapeutics. In future, clear algorithm reflecting clinically importance of each marker will be required for the routine diagnostics in NSCLC because of limited sample material. New methodologies combining currently using methods able to evaluate several markers simultaneously will be needed for appropriate NSCLC patient care management.

In conclusion, EGFR mutations and EML4-ALK rearrangement are currently the strongest predictive markers and only clinically applicable markers for patient selection to targeted therapy in NSCLC.

\section{ACKNOWLEDGEMENTS}

Supported by grants 303/09/H048, IGA NT13569, IGA UP LF_2013_015 and CZ.1.05/2.1.00/01.0030.

\section{CONFLICT OF INTEREST STATEMENT}

Author's conflict of interest disclosure. The authors stated that there are no conflicts of interest regarding the publication of this article.

\section{REFERENCES}

1. Jemal A, Siegel R, Ward E, Hao Y, Xu J, Thun MJ. Cancer statistics, 2009. CA Cancer J Clin 2009;59:225-49.

2. Jemal A, Bray F, Center MM, Ferlay J, Ward E, Forman D. Global cancer statistics. CA Cancer J Clin 2011;61:69-90.

3. Ettinger DS, Akerley W, Bepler G, Blum MG, Chang A, Cheney RT, Chirieac LR, D'Amico TA, Demmy TL, Ganti AK, Govindan R, Grannis FW, Jr., Jahan T, Jahanzeb M, Johnson DH, Kessinger A, Komaki R, Kong FM, Kris MG, Krug LM, Le QT, Lennes IT, Martins R, O'Malley J, Osarogiagbon RU, Otterson GA, Patel JD, Pisters KM, Reckamp K, Riely GJ, Rohren E, Simon GR, Swanson SJ, Wood DE, Yang SC. Nonsmall cell lung cancer. J Natl Compr Canc Netw 2010;8:740-801.
4. Pao W, Girard N. New driver mutations in non-small-cell lung cancer. Lancet Oncol 2011;12:175-80.

5. Huang SM, Harari PM. Epidermal growth factor receptor inhibition in cancer therapy: biology, rationale and preliminary clinical results. Invest New Drugs 1999;17:259-69.

6. Gazdar AF. Activating and resistance mutations of EGFR in nonsmall-cell lung cancer: role in clinical response to EGFR tyrosine kinase inhibitors. Oncogene 2009;28 Suppl 1:S24-S31.

7. Hirsch FR, Herbst RS, Olsen C, Chansky K, Crowley J, Kelly K, Franklin WA, Bunn PA, Jr., Varella-Garcia M, Gandara DR. Increased EGFR gene copy number detected by fluorescent in situ hybridization predicts outcome in non-small-cell lung cancer patients treated with cetuximab and chemotherapy. J Clin Oncol 2008;26:3351-7.

8. Li AR, Chitale D, Riely GJ, Pao W, Miller VA, Zakowski MF, Rusch V, Kris MG, Ladanyi M. EGFR mutations in lung adenocarcinomas: clinical testing experience and relationship to EGFR gene copy number and immunohistochemical expression. J Mol Diagn 2008;10:242-8.

9. Cappuzzo F, Hirsch FR, Rossi E, Bartolini S, Ceresoli GL, Bemis L, Haney J, Witta S, Danenberg K, Domenichini I, Ludovini V, Magrini E, Gregorc V, Doglioni C, Sidoni A, Tonato M, Franklin WA, Crino L, Bunn PA, Jr., Varella-Garcia M. Epidermal growth factor receptor gene and protein and gefitinib sensitivity in non-small-cell lung cancer. J Natl Cancer Inst 2005;97:643-55.

10. Dacic S, Flanagan M, Cieply K, Ramalingam S, Luketich J, Belani C, Yousem SA. Significance of EGFR protein expression and gene amplification in non-small cell lung carcinoma. Am J Clin Pathol 2006;125:860-5.

11. Hirsch FR, Varella-Garcia M, McCoy J, West H, Xavier AC, Gumerlock P, Bunn PA, Jr., Franklin WA, Crowley J, Gandara DR. Increased epidermal growth factor receptor gene copy number detected by fluorescence in situ hybridization associates with increased sensitivity to gefitinib in patients with bronchioloalveolar carcinoma subtypes: a Southwest Oncology Group Study. J Clin Oncol 2005;23:6838-45.

12. Hirsch FR, Varella-Garcia M, Bunn PA, Jr., Di Maria MV, Veve R, Bremmes RM, Baron AE, Zeng C, Franklin WA. Epidermal growth factor receptor in non-small-cell lung carcinomas: correlation between gene copy number and protein expression and impact on prognosis. J Clin Oncol 2003;21:3798-807.

13. Meert AP, Martin B, Delmotte P, Berghmans T, Lafitte JJ, Mascaux C, Paesmans M, Steels E, Verdebout JM, Sculier JP. The role of EGF-R expression on patient survival in lung cancer: a systematic review with meta-analysis. Eur Respir J 2002;20:975-81.

14. Nakamura H, Kawasaki N, Taguchi M, Kabasawa K. Survival impact of epidermal growth factor receptor overexpression in patients with non-small cell lung cancer: a meta-analysis. Thorax 2006;61:140-5.

15. Cappuzzo F, Ligorio C, Janne PA, Toschi L, Rossi E, Trisolini R, Paioli D, Holmes AJ, Magrini E, Finocchiaro G, Bartolini S, Cancellieri A, Ciardiello F, Patelli M, Crino L, Varella-Garcia M. Prospective study of gefitinib in epidermal growth factor receptor fluorescence in situ hybridization-positive/phospho-Akt-positive or never smoker patients with advanced non-small-cell lung cancer: the ONCOBELL trial. J Clin Oncol 2007;25:2248-55.

16. Hirsch FR, Varella-Garcia M, Bunn PA, Jr., Franklin WA, Dziadziuszko R, Thatcher N, Chang A, Parikh P, Pereira JR, Ciuleanu T, von PJ, Watkins C, Flannery A, Ellison G, Donald E, Knight L, Parums D, Botwood $\mathrm{N}$, Holloway B. Molecular predictors of outcome with gefitinib in a phase III placebo-controlled study in advanced non-small-cell lung cancer. J Clin Oncol 2006;24:5034-42.

17. Zhu CQ, da Cunha SG, Ding K, Sakurada A, Cutz JC, Liu N, Zhang T, Marrano P, Whitehead M, Squire JA, Kamel-Reid S, Seymour L, Shepherd FA, Tsao MS. Role of KRAS and EGFR as biomarkers of response to erlotinib in National Cancer Institute of Canada Clinical Trials Group Study BR.21. J Clin Oncol 2008;26:4268-75.

18. Crino L, Cappuzzo F, Zatloukal P, Reck M, Pesek M, Thompson JC, Ford HE, Hirsch FR, Varella-Garcia M, Ghiorghiu S, Duffield EL, Armour AA, Speake G, Cullen M. Gefitinib versus vinorelbine in chemotherapynaive elderly patients with advanced non-small-cell lung cancer (INVITE): a randomized, phase II study. J Clin Oncol 2008;26:4253-60.

19. Sasaki H, Endo K, Okuda K, Kawano O, Kitahara N, Tanaka H, Matsumura A, luchi K, Takada M, Kawahara M, Kawaguchi T, Yukiue $\mathrm{H}$, Yokoyama T, Yano M, Fujii Y. Epidermal growth factor receptor gene amplification and gefitinib sensitivity in patients with recurrent lung cancer. J Cancer Res Clin Oncol 2008;134:569-77.

20. Dahabreh IJ, Linardou H, Kosmidis P, Bafaloukos D, Murray S. EGFR gene copy number as a predictive biomarker for patients receiving 
tyrosine kinase inhibitor treatment: a systematic review and metaanalysis in non-small-cell lung cancer. Ann Oncol 2011;22:545-52.

21. Brugger W, Triller N, Blasinska-Morawiec M, Curescu S, Sakalauskas R, Manikhas GM, Mazieres J, Whittom R, Ward C, Mayne K, Trunzer K, Cappuzzo F. Prospective Molecular Marker Analyses of EGFR and KRAS From a Randomized, Placebo-Controlled Study of Erlotinib Maintenance Therapy in Advanced Non-Small-Cell Lung Cancer. J Clin Oncol 2011;29:4113-20.

22. Hirsch FR, Kabbinavar F, Eisen T, Martins R, Schnell FM, Dziadziuszko R, Richardson K, Richardson F, Wacker B, Sternberg DW, Rusk J, Franklin WA, Varella-Garcia M, Bunn PA, Jr., Camidge DR. A randomized, phase II, biomarker-selected study comparing erlotinib to erlotinib intercalated with chemotherapy in first-line therapy for advanced non-small-cell lung cancer. J Clin Oncol 2011;29:3567-73.

23. Morinaga R, Okamoto I, Fujita $Y$, Arao T, Sekijima M, Nishio K, Ito $H$ Fukuoka M, Kadota J, Nakagawa K. Association of epidermal growth factor receptor (EGFR) gene mutations with EGFR amplification in advanced non-small cell lung cancer. Cancer Sci 2008;99:2455-60.

24. Lynch TJ, Bell DW, Sordella R, Gurubhagavatula S, Okimoto RA Brannigan BW, Harris PL, Haserlat SM, Supko JG, Haluska FG, Louis DN, Christiani DC, Settleman J, Haber DA. Activating mutations in the epidermal growth factor receptor underlying responsiveness of non-small-cell lung cancer to gefitinib. N Engl J Med 2004;350:212939

25. Paez JG, Janne PA, Lee JC, Tracy S, Greulich H, Gabriel S, Herman P, Kaye FJ, Lindeman N, Boggon TJ, Naoki K, Sasaki H, Fujii Y, Eck MJ, Sellers WR, Johnson BE, Meyerson M. EGFR mutations in lung cancer: correlation with clinical response to gefitinib therapy. Science 2004;304:1497-500.

26. Forbes S, Clements J, Dawson E, Bamford S, Webb T, Dogan A Flanagan A, Teague J, Wooster R, Futreal PA, Stratton MR. COSMIC 2005. Br J Cancer 2006;94:318-22.

27. Kosaka T, Yamaki E, Mogi A, Kuwano H. Mechanisms of resistance to EGFR TKIs and development of a new generation of drugs in nonsmall-cell lung cancer. J Biomed Biotechnol 2011;2011:165214.

28. Ciardiello F, Caputo R, Bianco R, Damiano V, Pomatico G, De PS, Bianco AR, Tortora G. Antitumor effect and potentiation of cytotoxic drugs activity in human cancer cells by ZD-1839 (Iressa), an epidermal growth factor receptor-selective tyrosine kinase inhibitor. Clin Cancer Res 2000;6:2053-63.

29. Herbst RS, Maddox AM, Rothenberg ML, Small EJ, Rubin EH, Baselga J, Rojo F, Hong WK, Swaisland H, Averbuch SD, Ochs J, LoRusso PM. Selective oral epidermal growth factor receptor tyrosine kinase inhibitor ZD1839 is generally well-tolerated and has activity in nonsmall-cell lung cancer and other solid tumors: results of a phase trial. J Clin Oncol 2002;20:3815-25.

30. Ranson M, Hammond LA, Ferry D, Kris M, Tullo A, Murray PI, Miller V Averbuch S, Ochs J, Morris C, Feyereislova A, Swaisland H, Rowinsky EK. ZD1839, a selective oral epidermal growth factor receptortyrosine kinase inhibitor, is well tolerated and active in patients with solid, malignant tumors: results of a phase I trial. J Clin Oncol 2002;20:2240-50.

31. Fukuoka M, Yano S, Giaccone G, Tamura T, Nakagawa K, Douillard JY, Nishiwaki Y, Vansteenkiste J, Kudoh S, Rischin D, Eek R, Horai T, Noda K, Takata I, Smit E, Averbuch S, Macleod A, Feyereislova A, Dong RP, Baselga J. Multi-institutional randomized phase II trial of gefitinib for previously treated patients with advanced non-small-cell lung cancer (The IDEAL 1 Trial) [corrected]. J Clin Oncol 2003;21:2237-46.

32. Kris MG, Natale RB, Herbst RS, Lynch TJ, Jr., Prager D, Belani CP, Schiller JH, Kelly K, Spiridonidis H, Sandler A, Albain KS, Cella D, Wolf MK, Averbuch SD, Ochs JJ, Kay AC. Efficacy of gefitinib, an inhibitor of the epidermal growth factor receptor tyrosine kinase, in symptomatic patients with non-small cell lung cancer: a randomized trial. JAMA 2003;290:2149-58.

33. Armour AA, Watkins CL. The challenge of targeting EGFR: experience with gefitinib in nonsmall cell lung cancer. Eur Respir Rev 2010;19:186-96.

34. Mok TS, Wu YL, Thongprasert S, Yang CH, Chu DT, Saijo N, Sunpaweravong $\mathrm{P}$, Han B, Margono B, Ichinose Y, Nishiwaki Y, Ohe Y, Yang JJ, Chewaskulyong B, Jiang H, Duffield EL, Watkins CL, Armour AA, Fukuoka M. Gefitinib or carboplatin-paclitaxel in pulmonary adenocarcinoma. N Engl J Med 2009;361:947-57.

35. Hidalgo M, Siu LL, Nemunaitis J, Rizzo J, Hammond LA, Takimoto C, Eckhardt SG, Tolcher A, Britten CD, Denis L, Ferrante K, Von Hoff DD, Silberman S, Rowinsky EK. Phase I and pharmacologic study of
OSI-774, an epidermal growth factor receptor tyrosine kinase inhibitor, in patients with advanced solid malignancies. J Clin Oncol 2001;19:3267-79.

36. Shepherd FA, Rodrigues PJ, Ciuleanu T, Tan EH, Hirsh V, Thongprasert S, Campos D, Maoleekoonpiroj S, Smylie M, Martins R, van KM, Dediu M, Findlay B, Tu D, Johnston D, Bezjak A, Clark G, Santabarbara P, Seymour L. Erlotinib in previously treated non-small-cell lung cancer. N Engl J Med 2005;353:123-32.

37. Dahabreh IJ, Linardou H, Siannis F, Kosmidis P, Bafaloukos D, Murray S. Somatic EGFR mutation and gene copy gain as predictive biomarkers for response to tyrosine kinase inhibitors in non-small cell lung cancer. Clin Cancer Res 2010;16:291-303.

38. Dienstmann R, Martinez P, Felip E. Personalizing therapy with targeted agents in non-small cell lung cancer. Oncotarget 2011;2:16577.

39. Petrelli F, Borgonovo K, Cabiddu M, Barni S. Efficacy of EGFR tyrosine kinase inhibitors in patients with EGFR-mutated non-small-cell lung cancer: a meta-analysis of 13 randomized trials. Clin Lung Cancer 2012;13:107-14.

40. Patil N, Abba M, Allgayer H. Cetuximab and biomarkers in non-smallcell lung carcinoma. Biologics 2012;6:221-31.

41. Khambata-Ford S, Harbison CT, Hart LL, Awad M, Xu LA, Horak CE, Dakhil S, Hermann RC, Lynch TJ, Weber MR. Analysis of potential predictive markers of cetuximab benefit in BMS099, a phase III study of cetuximab and first-line taxane/carboplatin in advanced nonsmall-cell lung cancer. J Clin Oncol 2010;28:918-27.

42. Lin $\mathrm{H}$, Jiang J, Liang $X$, Zhou $X$, Huang R. Chemotherapy with cetuXimab or chemotherapy alone for untreated advanced non-small-cell lung cancer: a systematic review and meta-analysis. Lung Cancer 2010;70:57-62.

43. Greulich $\mathrm{H}$, Chen TH, Feng W, Janne PA, Alvarez JV, Zappaterra M, Bulmer SE, Frank DA, Hahn WC, Sellers WR, Meyerson M. Oncogenic transformation by inhibitor-sensitive and -resistant EGFR mutants. PLoS Med 2005;2:e313.

44. Sequist LV, Martins RG, Spigel D, Grunberg SM, Spira A, Janne PA, Joshi VA, McCollum D, Evans TL, Muzikansky A, Kuhlmann GL, Han M, Goldberg JS, Settleman J, lafrate AJ, Engelman JA, Haber DA, Johnson BE, Lynch TJ. First-line gefitinib in patients with advanced non-small-cell lung cancer harboring somatic EGFR mutations. J Clin Oncol 2008;26:2442-9.

45. Yasuda H, Kobayashi S, Costa DB. EGFR exon 20 insertion mutations in non-small-cell lung cancer: preclinical data and clinical implications. Lancet Oncol 2012;13:e23-e31.

46. Mok TS, Wu YL, Thongprasert S, Yang CH, Chu DT, Saijo N, Sunpaweravong P, Han B, Margono B, Ichinose Y, Nishiwaki Y, Ohe Y, Yang JJ, Chewaskulyong B, Jiang $H$, Duffield EL, Watkins CL, Armour AA, Fukuoka M. Gefitinib or carboplatin-paclitaxel in pulmonary adenocarcinoma. N Engl J Med 2009;361:947-57.

47. Rosell R, Molina MA, Costa C, Simonetti S, Gimenez-Capitan A Bertran-Alamillo J, Mayo C, Moran T, Mendez P, Cardenal F, Isla D, Provencio M, Cobo M, Insa A, Garcia-Campelo R, Reguart N, Majem M, Viteri S, Carcereny E, Porta R, Massuti B, Queralt C, de A, I, Sanchez JM, Sanchez-Ronco M, Mate JL, Ariza A, Benlloch S, Sanchez JJ, Bivona TG, Sawyers CL, Taron M. Pretreatment EGFR T790M mutation and BRCA1 mRNA expression in erlotinib-treated advanced nonsmall-cell lung cancer patients with EGFR mutations. Clin Cancer Res 2011;17:1160-8.

48. Maheswaran S, Sequist LV, Nagrath S, Ulkus L, Brannigan B, Collura CV, Inserra E, Diederichs S, lafrate AJ, Bell DW, Digumarthy S, Muzikansky A, Irimia D, Settleman J, Tompkins RG, Lynch TJ, Toner $M$, Haber DA. Detection of mutations in EGFR in circulating lungcancer cells. N Engl J Med 2008;359:366-77.

49. Wu JY, Yu CJ, Chang YC, Yang CH, Shih JY, Yang PC. Effectiveness of tyrosine kinase inhibitors on "uncommon" epidermal growth factor receptor mutations of unknown clinical significance in non-small cell lung cancer. Clin Cancer Res 2011;17:3812-21.

50. Wang SE, Narasanna A, Perez-Torres M, Xiang B, Wu FY, Yang S, Carpenter G, Gazdar AF, Muthuswamy SK, Arteaga CL. HER2 kinase domain mutation results in constitutive phosphorylation and activation of HER2 and EGFR and resistance to EGFR tyrosine kinase inhibitors. Cancer Cell 2006;10:25-38.

51. Cappuzzo F, Bemis L, Varella-Garcia M. HER2 mutation and response to trastuzumab therapy in non-small-cell lung cancer. N Engl J Med 2006;354:2619-21. 
52. Nguyen KS, Kobayashi S, Costa DB. Acquired resistance to epidermal growth factor receptor tyrosine kinase inhibitors in non-small-cell lung cancers dependent on the epidermal growth factor receptor pathway. Clin Lung Cancer 2009;10:281-9.

53. Ghosh G, Lian X, Kron SJ, Palecek SP. Properties of resistant cells generated from lung cancer cell lines treated with EGFR inhibitors. BMC Cancer 2012;12:95.

54. Kobayashi S, Boggon TJ, Dayaram T, Janne PA, Kocher O, Meyerson M, Johnson BE, Eck MJ, Tenen DG, Halmos B. EGFR mutation and resistance of non-small-cell lung cancer to gefitinib. N Engl J Med 2005;352:786-92.

55. Pao W, Miller VA, Politi KA, Riely GJ, Somwar R, Zakowski MF, Kris MG, Varmus $\mathrm{H}$. Acquired resistance of lung adenocarcinomas to gefitinib or erlotinib is associated with a second mutation in the EGFR kinase domain. PLoS Med 2005;2:e73.

56. Balak MN, Gong Y, Riely GJ, Somwar R, Li AR, Zakowski MF, Chiang A, Yang G, Ouerfelli O, Kris MG, Ladanyi M, Miller VA, Pao W. Novel D761Y and common secondary T790M mutations in epiderma growth factor receptor-mutant lung adenocarcinomas with acquired resistance to kinase inhibitors. Clin Cancer Res 2006;12:6494501.

57. Engelman JA, Zejnullahu K, Mitsudomi T, Song Y, Hyland C, Park JO, Lindeman N, Gale CM, Zhao X, Christensen J, Kosaka T, Holmes AJ, Rogers AM, Cappuzzo F, MokT, Lee C, Johnson BE, Cantley LC, Janne PA. MET amplification leads to gefitinib resistance in lung cancer by activating ERBB3 signaling. Science 2007;316:1039-43.

58. Kosaka T, Yatabe Y, Endoh H, Yoshida K, Hida T, Tsuboi M, Tada H, Kuwano $\mathrm{H}$, Mitsudomi T. Analysis of epidermal growth factor receptor gene mutation in patients with non-small cell lung cancer and acquired resistance to gefitinib. Clin Cancer Res 2006;12:5764-9.

59. Yun $\mathrm{CH}$, Mengwasser KE, Toms AV, Woo MS, Greulich H, Wong KK, Meyerson M, Eck MJ. The T790M mutation in EGFR kinase causes drug resistance by increasing the affinity for ATP. Proc Natl Acad Sc U S A 2008;105:2070-5.

60. Riely GJ, Kris MG, Rosenbaum D, Marks J, Li A, Chitale DA, Nafa K, Riedel ER, Hsu M, Pao W, Miller VA, Ladanyi M. Frequency and distinctive spectrum of KRAS mutations in never smokers with lung adenocarcinoma. Clin Cancer Res 2008;14:5731-4.

61. Vakiani E, Solit DB. KRAS and BRAF: drug targets and predictive biomarkers. J Pathol 2011;223:219-29.

62. Okudela K, Woo T, Kitamura H. KRAS gene mutations in lung cancer: particulars established and issues unresolved. Pathol Int 2010;60:651-60.

63. Tam IY, Chung LP, Suen WS, Wang E, Wong MC, Ho KK, Lam WK, Chiu SW, Girard L, Minna JD, Gazdar AF, Wong MP. Distinct epiderma growth factor receptor and KRAS mutation patterns in non-smal cell lung cancer patients with different tobacco exposure and clinicopathologic features. Clin Cancer Res 2006;12:1647-53.

64. Mao C, Qiu LX, Liao RY, Du FB, Ding H, Yang WC, Li J, Chen Q. KRAS mutations and resistance to EGFR-TKIs treatment in patients with non-small cell lung cancer: a meta-analysis of 22 studies. Lung Cancer 2010;69:272-8

65. Pao W, Wang TY, Riely GJ, Miller VA, Pan Q, Ladanyi M, Zakowski MF Heelan RT, Kris MG, Varmus HE. KRAS mutations and primary resistance of lung adenocarcinomas to gefitinib or erlotinib. PLoS Med 2005;2:e17.

66. Kosaka T, Yatabe Y, Endoh H, Kuwano H, Takahashi T, Mitsudomi T. Mutations of the epidermal growth factor receptor gene in lung cancer: biological and clinical implications. Cancer Res 2004;64:8919-23.

67. Kosaka T, Yatabe Y, Onozato R, Kuwano H, Mitsudomi T. Prognostic implication of EGFR, KRAS, and TP53 gene mutations in a large cohort of Japanese patients with surgically treated lung adenocarcinoma. J Thorac Oncol 2009;4:22-9.

68. Marks JL, Broderick S, Zhou Q, Chitale D, Li AR, Zakowski MF, Kris MG, Rusch VW, Azzoli CG, Seshan VE, Ladanyi M, Pao W. Prognostic and therapeutic implications of EGFR and KRAS mutations in resected lung adenocarcinoma. J Thorac Oncol 2008;3:111-6.

69. Han SW, Kim TY, Jeon YK, Hwang PG, Im SA, Lee KH, Kim JH, Kim DW, Heo DS, Kim NK, Chung DH, Bang YJ. Optimization of patient selection for gefitinib in non-small cell lung cancer by combined analysis of epidermal growth factor receptor mutation, K-ras mutation, and Akt phosphorylation. Clin Cancer Res 2006;12:2538-44.

70. Mascaux C, lannino N, Martin B, Paesmans M, Berghmans T, Dusart M, Haller A, Lothaire P, Meert AP, Noel S, Lafitte JJ, Sculier JP. The role of RAS oncogene in survival of patients with lung cancer: a systematic review of the literature with meta-analysis. Br J Cancer 2005;92:131-9.

71. Dean M, Park M, Le Beau MM, Robins TS, Diaz MO, Rowley JD, Blair DG, Vande Woude GF. The human met oncogene is related to the tyrosine kinase oncogenes. Nature 1985;318:385-8.

72. Lutterbach B, Zeng Q, Davis LJ, Hatch H, Hang G, Kohl NE, Gibbs JB, Pan BS. Lung cancer cell lines harboring MET gene amplification are dependent on Met for growth and survival. Cancer Res 2007;67:2081-8.

73. Peruzzi B, Bottaro DP. Targeting the $c-$ Met signaling pathway in cancer. Clin Cancer Res 2006;12:3657-60.

74. Furge KA, Zhang YW, Vande Woude GF. Met receptor tyrosine kinase: enhanced signaling through adapter proteins. Oncogene 2000;19:5582-9.

75. Trusolino L, Bertotti A, Comoglio PM. MET signalling: principles and functions in development, organ regeneration and cancer. Nat Rev Mol Cell Biol 2010;11:834-48.

76. Cooper CS, Park M, Blair DG, Tainsky MA, Huebner K, Croce CM Vande Woude GF. Molecular cloning of a new transforming gene from a chemically transformed human cell line. Nature 1984;311:2933.

77. Knudsen BS, Vande WG. Showering c-MET-dependent cancers with drugs. Curr Opin Genet Dev 2008;18:87-96.

78. Peruzzi $B$, Bottaro DP. Targeting the $c-$ Met signaling pathway in cancer. Clin Cancer Res 2006;12:3657-60.

79. Giordano S, Bardelli A, Zhen Z, Menard S, Ponzetto C, Comoglio PM. A point mutation in the MET oncogene abrogates metastasis without affecting transformation. Proc Natl Acad Sci U S A 1997;94:13868-72.

80. Schmidt L, Duh FM, Chen F, Kishida T, Glenn G, Choyke P, Scherer SW, Zhuang Z, Lubensky I, Dean M, Allikmets R, Chidambaram A, Bergerheim UR, Feltis JT, Casadevall C, Zamarron A, Bernues M, Richard S, Lips CJ, Walther MM, Tsui LC, Geil L, Orcutt ML, Stackhouse T, Lipan J, Slife L, Brauch H, Decker J, Niehans G, Hughson MD, Moch $\mathrm{H}$, Storkel S, Lerman MI, Linehan WM, Zbar B. Germline and somatic mutations in the tyrosine kinase domain of the MET proto-oncogene in papillary renal carcinomas. Nat Genet 1997;16:68-73.

81. Smolen GA, Sordella R, Muir B, Mohapatra G, Barmettler A, Archibald $\mathrm{H}$, Kim WJ, Okimoto RA, Bell DW, Sgroi DC, Christensen JG, Settleman J, Haber DA. Amplification of MET may identify a subset of cancers with extreme sensitivity to the selective tyrosine kinase inhibitor PHA-665752. Proc Natl Acad Sci U S A 2006;103:2316-21.

82. Birchmeier C, Birchmeier W, Gherardi E, Vande Woude GF. Met, metastasis, motility and more. Nat Rev Mol Cell Biol 2003;4:915-25.

83. Beau-Faller M, Ruppert AM, Voegeli AC, Neuville A, Meyer N, Guerin E, Legrain M, Mennecier B, Wihlm JM, Massard G, Quoix E, Oudet P, Gaub MP. MET gene copy number in non-small cell lung cancer: molecular analysis in a targeted tyrosine kinase inhibitor naive cohort. JThorac Oncol 2008;3:331-9.

84. Cappuzzo F, Marchetti A, Skokan M, Rossi E, Gajapathy S, Felicioni L, Del GM, Sciarrotta MG, Buttitta F, Incarbone M, Toschi L, Finocchiaro G, Destro A, Terracciano L, Roncalli M, Alloisio M, Santoro A, VarellaGarcia M. Increased MET gene copy number negatively affects survival of surgically resected non-small-cell lung cancer patients. J Clin Oncol 2009;27:1667-74

85. Go H, Jeon YK, Park HJ, Sung SW, Seo JW, Chung DH. High MET gene copy number leads to shorter survival in patients with non-small cell lung cancer. J Thorac Oncol 2010;5:305-13.

86. Tanaka A, Sueoka-Aragane N, Nakamura T, Takeda Y, Mitsuoka M, Yamasaki F, Hayashi S, Sueoka E, Kimura S. Co-existence of positive MET FISH status with EGFR mutations signifies poor prognosis in lung adenocarcinoma patients. Lung Cancer 2011.

87. Okuda K, Sasaki H, Yukiue H, Yano M, Fujii Y. Met gene copy number predicts the prognosis for completely resected non-small cell lung cancer. Cancer Sci 2008;99:2280-5.

88. Bean J, Brennan C, Shih JY, Riely G, Viale A, Wang L, Chitale D, Motoi N, Szoke J, Broderick S, Balak M, Chang WC, Yu CJ, Gazdar A, Pass H, Rusch V, Gerald W, Huang SF, Yang PC, Miller V, Ladanyi M, Yang CH, Pao W. MET amplification occurs with or without T790M mutations in EGFR mutant lung tumors with acquired resistance to gefitinib or erlotinib. Proc Natl Acad Sci U S A 2007;104:20932-7.

89. Cappuzzo F, Janne PA, Skokan M, Finocchiaro G, Rossi E, Ligorio C, Zucali PA, Terracciano L, Toschi L, Roncalli M, Destro A, Incarbone M, Alloisio M, Santoro A, Varella-Garcia M. MET increased gene copy 
number and primary resistance to gefitinib therapy in non-small-cell lung cancer patients. Ann Oncol 2009;20:298-304.

90. Benedettini E, Sholl LM, Peyton M, Reilly J, Ware C, Davis L, Vena N, Bailey D, Yeap BY, Fiorentino M, Ligon AH, Pan BS, Richon V, Minna JD, Gazdar AF, Draetta G, Bosari S, Chirieac LR, Lutterbach B, Loda $M$. Met activation in non-small cell lung cancer is associated with de novo resistance to EGFR inhibitors and the development of brain metastasis. Am J Pathol 2010;177:415-23.

91. Navab R, Liu J, Seiden-Long I, Shih W, Li M, Bandarchi B, Chen Y, Lau D, Zu YF, Cescon D, Zhu CQ, Organ S, Ibrahimov E, Ohanessian D, Tsao MS. Co-overexpression of Met and hepatocyte growth factor promotes systemic metastasis in $\mathrm{NCl}-\mathrm{H} 460$ non-small cell lung carcinoma cells. Neoplasia 2009;11:1292-300.

92. McDermott U, Pusapati RV, Christensen JG, Gray NS, Settleman J. Acquired resistance of non-small cell lung cancer cells to MET kinase inhibition is mediated by a switch to epidermal growth factor receptor dependency. Cancer Res 2010;70:1625-34.

93. Sequist LV, Waltman BA, Dias-Santagata D, Digumarthy S, Turke AB, Fidias P, Bergethon K, Shaw AT, Gettinger S, Cosper AK, Akhavanfard S, Heist RS, Temel J, Christensen JG, Wain JC, Lynch TJ, Vernovsky K, Mark EJ, Lanuti M, lafrate AJ, Mino-Kenudson M, Engelman JA. Genotypic and histological evolution of lung cancers acquiring resistance to EGFR inhibitors. Sci Transl Med 2011;3:75ra26.

94. Suda K, Murakami I, Katayama T, Tomizawa K, Osada H, Sekido Y, Maehara Y, Yatabe Y, Mitsudomi T. Reciprocal and complementary role of MET amplification and EGFR T790M mutation in acquired resistance to kinase inhibitors in lung cancer. Clin Cancer Res 2010;16:5489-98.

95. Turke AB, Zejnullahu K, Wu YL, Song Y, Dias-Santagata D, Lifshits E, Toschi L, Rogers A, Mok T, Sequist L, Lindeman NI, Murphy C, Akhavanfard S, Yeap BY, Xiao Y, Capelletti M, lafrate AJ, Lee C, Christensen JG, Engelman JA, Janne PA. Preexistence and clonal selection of MET amplification in EGFR mutant NSCLC. Cancer Cell 2010;17:77-88

96. Matsubara D, Ishikawa S, Oguni S, Aburatani H, Fukayama M, Niki T. Molecular predictors of sensitivity to the MET inhibitor PHA665752 in lung carcinoma cells. J Thorac Oncol 2010;5:1317-24.

97. Buchanan SG, Hendle J, Lee PS, Smith CR, Bounaud PY, Jessen KA, Tang CM, Huser NH, Felce JD, Froning KJ, Peterman MC, Aubol BE, Gessert SF, Sauder JM, Schwinn KD, Russell M, Rooney IA, Adams J, Leon BC, Do TH, Blaney JM, Sprengeler PA, Thompson DA, Smyth L, Pelletier LA, Atwell S, Holme K, Wasserman SR, Emtage S, Burley SK, Reich SH. SGX523 is an exquisitely selective, ATP-competitive inhibitor of the MET receptor tyrosine kinase with antitumor activity in vivo. Mol Cancer Ther 2009;8:3181-90.

98. Zhang YW, Staal B, Essenburg C, Su Y, Kang L, West R, Kaufman D, Dekoning T, Eagleson B, Buchanan SG, Vande Woude GF. MET kinase inhibitor SGX523 synergizes with epidermal growth factor receptor inhibitor erlotinib in a hepatocyte growth factor-dependent fashion to suppress carcinoma growth. Cancer Res 2010;70:6880-90.

99. Adjei AA, Schwartz B, Garmey E. Early clinical development of ARO 197, a selective, non-ATP-competitive inhibitor targeting MET tyrosine kinase for the treatment of advanced cancers. Oncologist 2011;16:788-99.

100. Munshi N, Jeay S, Li Y, Chen CR, France DS, Ashwell MA, Hill J, Moussa MM, Leggett DS, Li CJ. ARQ 197, a novel and selective inhibitor of the human c-Met receptor tyrosine kinase with antitumor activity. Mol Cancer Ther 2010;9:1544-53.

101. Yakes FM, Chen J, Tan J, Yamaguchi K, Shi Y, Yu P, Qian F, Chu F, Bentzien F, Cancilla B, Orf J, You A, Laird AD, Engst S, Lee L, Lesch J, Chou YC, Joly A. Cabozantinib (XL184), a novel MET and VEGFR2 inhibitor, simultaneously suppresses metastasis, angiogenesis, and tumor growth. Mol Cancer Ther 2011.

102. Surati M, Patel P, Peterson A, Salgia R. Role of MetMAb (OA-5D5) in cMET active lung malignancies. Expert Opin Biol Ther 2011;11:165562.

103. U.S.National Library of Medicine. A service of the U.S. National Institutes of Health [online]. [cited 2012 Dec 8]; Available from: http://www clinicaltrials gov/.

104. Sequist LV, von PJ, Garmey EG, Akerley WL, Brugger W, Ferrari D, Chen Y, Costa DB, Gerber DE, Orlov S, Ramlau R, Arthur S, Gorbachevsky I, Schwartz B, Schiller JH. Randomized phase II study of erlotinib plus tivantinib versus erlotinib plus placebo in previously treated non-small-cell lung cancer. J Clin Oncol 2011;29:330715.
105. Tanizaki J, Okamoto I, Okamoto K, Takezawa K, Kuwata K, Yamaguchi $\mathrm{H}$, Nakagawa K. MET tyrosine kinase inhibitor crizotinib (PF-02341066) shows differential antitumor effects in nonsmall cell lung cancer according to MET alterations. JThorac Oncol 2011;6:1624-31.

106. Ou SH, Kwak EL, Siwak-Tapp C, Dy J, Bergethon K, Clark JW, Camidge DR, Solomon BJ, Maki RG, Bang YJ, Kim DW, Christensen J, Tan W, Wilner KD, Salgia R, lafrate AJ. Activity of crizotinib (PF02341066), a dual mesenchymal-epithelial transition (MET) and anaplastic lymphoma kinase (ALK) inhibitor, in a non-small cell lung cancer patient with de novo MET amplification. J Thorac Oncol 2011;6:942-6.

107. Yang M, Shan B, Li Q, Song X, Cai J, Deng J, Zhang L, Du Z, Lu J, Chen T, Wery JP, Chen Y, Li Q. Overcoming erlotinib resistance with tailored treatment regimen in patient-derived xenografts from naive Asian NSCLC patients. Int J Cancer 2013;132:E74-E84.

108. Morris SW, Kirstein MN, Valentine MB, Dittmer KG, Shapiro DN, Saltman DL, Look AT. Fusion of a kinase gene, ALK, to a nucleolar protein gene, NPM, in non-Hodgkin's lymphoma. Science 1994;263:1281-4.

109. Martelli MP, Sozzi G, Hernandez L, Pettirossi V, Navarro A, Conte D, Gasparini P, Perrone F, Modena P, Pastorino U, Carbone A, Fabbri A, Sidoni A, Nakamura S, Gambacorta M, Fernandez PL, Ramirez J, Chan JK, Grigioni WF, Campo E, Pileri SA, Falini B. EML4-ALK rearrangement in non-small cell lung cancer and non-tumor lung tissues. Am J Pathol 2009;174:661-70.

110. Chen Y, Takita J, Choi YL, Kato M, Ohira M, Sanada M, Wang L, Soda M, Kikuchi A, Igarashi T, Nakagawara A, Hayashi Y, Mano H, Ogawa $\mathrm{S}$. Oncogenic mutations of ALK kinase in neuroblastoma. Nature 2008;455:971-4.

111. Griffin CA, Hawkins AL, Dvorak C, Henkle C, Ellingham T, Perlman EJ. Recurrent involvement of 2p23 in inflammatory myofibroblastic tumors. Cancer Res 1999;59:2776-80.

112. Soda M, Choi YL, Enomoto M, Takada S, Yamashita Y, Ishikawa S, Fujiwara S, Watanabe H, Kurashina K, Hatanaka H, Bando M, Ohno S, Ishikawa Y, Aburatani H, Niki T, Sohara Y, Sugiyama Y, Mano H. Identification of the transforming EML4-ALK fusion gene in nonsmall-cell lung cancer. Nature 2007;448:561-6.

113. Kwak EL, Bang YJ, Camidge DR, Shaw AT, Solomon B, Maki RG, Ou SH, Dezube BJ, Janne PA, Costa DB, Varella-Garcia M, Kim WH, Lynch TJ, Fidias P, Stubbs H, Engelman JA, Sequist LV, Tan W, Gandhi L, Mino-Kenudson M, Wei GC, Shreeve SM, Ratain MJ, Settleman J, Christensen JG, Haber DA, Wilner K, Salgia R, Shapiro Gl, Clark JW, lafrate AJ. Anaplastic lymphoma kinase inhibition in non-small-cell lung cancer. N Engl J Med 2010;363:1693-703.

114. Shaw AT, Yeap BY, Mino-Kenudson M, Digumarthy SR, Costa DB, Heist RS, Solomon B, Stubbs H, Admane S, McDermott U, Settleman J, Kobayashi S, Mark EJ, Rodig SJ, Chirieac LR, Kwak EL, Lynch TJ, lafrate AJ. Clinical features and outcome of patients with non-smallcell lung cancer who harbor EML4-ALK. J Clin Oncol 2009;27:424753.

115. Shaw AT, Yeap BY, Solomon BJ, Riely GJ, Gainor J, Engelman JA, Shapiro Gl, Costa DB, Ou SH, Butaney M, Salgia R, Maki RG, VarellaGarcia M, Doebele RC, Bang YJ, Kulig K, Selaru P, Tang Y, Wilner KD, Kwak EL, Clark JW, lafrate AJ, Camidge DR. Effect of crizotinib on overall survival in patients with advanced non-small-cell lung cancer harbouring ALK gene rearrangement: a retrospective analysis. Lancet Oncol 2011;12:1004-12.

116. Crystal AS, Shaw AT. New targets in advanced NSCLC: EML4-ALK. Clin Adv Hematol Oncol 2011;9:207-14.

117. Sasaki T, Rodig SJ, Chirieac LR, Janne PA. The biology and treatment of EML4-ALK non-small cell lung cancer. Eur J Cancer 2010;46:177380.

118. Horn L, Pao W. EML4-ALK: honing in on a new target in non-smallcell lung cancer. J Clin Oncol 2009;27:4232-5.

119. Penzel R, Schirmacher $P$, Warth A. A novel EML4-ALK variant: exon 6 of EML4 fused to exon 19 of ALK. J Thorac Oncol 2012;7:1198-9.

120. Dai Z, Kelly JC, Meloni-Ehrig A, Slovak ML, Boles D, Christacos NC, Bryke CR, Schonberg SA, Otani-Rosa J, Pan Q, Ho AK, Sanders HR, Zhang ZJ, Jones D, Mowrey PN. Incidence and patterns of ALK FISH abnormalities seen in a large unselected series of lung carcinomas. Mol Cytogenet 2012;5:44.

121. Takeuchi K, Choi YL, Togashi Y, Soda M, Hatano S, Inamura K, Takada S, Ueno T, Yamashita Y, Satoh Y, Okumura S, Nakagawa K, Ishikawa Y, Mano H. KIF5B-ALK, a novel fusion oncokinase identified by an 
immunohistochemistry-based diagnostic system for ALK-positive lung cancer. Clin Cancer Res 2009;15:3143-9.

122. Rikova K, Guo A, Zeng Q, Possemato A, Yu J, Haack H, Nardone J, Lee K, Reeves C, Li Y, Hu Y, Tan Z, Stokes M, Sullivan L, Mitchell J, Wetzel R, Macneill J, Ren JM, Yuan J, Bakalarski CE, Villen J, Kornhauser JM, Smith B, Li D, Zhou X, Gygi SP, Gu TL, Polakiewicz RD, Rush J, Comb MJ. Global survey of phosphotyrosine signaling identifies oncogenic kinases in lung cancer. Cell 2007;131:1190-203.

123. Togashi Y, Soda M, Sakata S, Sugawara E, Hatano S, Asaka R, Nakajima T, Mano H, Takeuchi K. KLC1-ALK: a novel fusion in lung cancer identified using a formalin-fixed paraffin-embedded tissue only. PLoS One 2012;7:e31323.

124. Kimura H, Nakajima T, Takeuchi K, Soda M, Mano H, lizasa T, Matsui Y, Yoshino M, Shingyoji M, Itakura M, Itami M, Ikebe D, Yokoi S, Kageyama $\mathrm{H}$, Ohira M, Nakagawara A. ALK fusion gene positive lung cancer and 3 cases treated with an inhibitor for ALK kinase activity. Lung Cancer 2011.

125. Heuckmann JM, Balke-Want H, Malchers F, Peifer M, Sos ML, Koker M, Meder L, Lovly CM, Heukamp LC, Pao W, Kuppers R, Thomas RK. Differential protein stability and ALK inhibitor sensitivity of EML4ALK fusion variants. Clin Cancer Res 2012;18:4682-90.

126. Salido M, Pijuan L, Martinez-Aviles L, Galvan AB, Canadas I, Rovira A, Zanui M, Martinez A, Longaron R, Sole F, Serrano S, Bellosillo B, Wynes MW, Albanell J, Hirsch FR, Arriola E. Increased ALK gene copy number and amplification are frequent in non-small cell lung cancer. J Thorac Oncol 2011;6:21-7.

127. Wong DW, Leung EL, So KK, Tam IY, Sihoe AD, Cheng LC, Ho KK, Au JS, Chung LP, Pik WM. The EML4-ALK fusion gene is involved in various histologic types of lung cancers from nonsmokers with wild-type EGFR and KRAS. Cancer 2009;115:1723-33.

128. Koivunen JP, Mermel C, Zejnullahu K, Murphy C, Lifshits E, Holmes AJ, Choi HG, Kim J, Chiang D, Thomas R, Lee J, Richards WG, Sugarbaker DJ, Ducko C, Lindeman N, Marcoux JP, Engelman JA, Gray NS, Lee C, Meyerson M, Janne PA. EML4-ALK fusion gene and efficacy of an ALK kinase inhibitor in lung cancer. Clin Cancer Res 2008;14:4275-83.

129. Takahashi T, Sonobe M, Kobayashi M, Yoshizawa A, Menju T, Nakayama E, Mino N, Iwakiri S, Sato K, Miyahara R, Okubo K, Manabe T, Date H. Clinicopathologic features of non-small-cell lung cancer with EML4-ALK fusion gene. Ann Surg Oncol 2010;17:889-97.

130. Kuo YW, Wu SG, Ho CC, Shih JY. Good response to gefitinib in lung adenocarcinoma harboring coexisting EML4-ALK fusion gene and EGFR mutation. J Thorac Oncol 2010;5:2039-40.

131. Popat S, Vieira de AA, Min T, Swansbury J, Dainton M, Wotherspoon A, Lim E, Nicholson AG, O'Brien ME. Lung adenocarcinoma with concurrent exon 19 EGFR mutation and ALK rearrangement responding to erlotinib. J Thorac Oncol 2011;6:1962-3.

132. Tiseo M, Gelsomino F, Boggiani D, Bortesi B, Bartolotti M, Bozzetti C, Sammarelli G, Thai E, Ardizzoni A. EGFR and EML4-ALK gene mutations in NSCLC: a case report of erlotinib-resistant patient with both concomitant mutations. Lung Cancer 2011;71:241-3.

133. Zhang X, Zhang S, Yang X, Yang J, Zhou Q, Yin L, An S, Lin J, Chen $S$, Xie Z, Zhu M, Zhang X, Wu YL. Fusion of EML4 and ALK is associated with development of lung adenocarcinomas lacking EGFR and KRAS mutations and is correlated with ALK expression. Mol Cancer 2010;9:188.

134. Doebele RC, Pilling AB, Aisner DL, Kutateladze TG, Le AT, Weickhardt AJ, Kondo KL, Linderman DJ, Heasley LE, Franklin WA, Varella-Garcia $M$, Camidge DR. Mechanisms of resistance to crizotinib in patients with ALK gene rearranged non-small cell lung cancer. Clin Cancer Res 2012;18:1472-82.

135. McDermott U, lafrate AJ, Gray NS, Shioda T, Classon M, Maheswaran S, Zhou W, Choi HG, Smith SL, Dowell L, Ulkus LE, Kuhlmann G, Greninger P, Christensen JG, Haber DA, Settleman J. Genomic al- terations of anaplastic lymphoma kinase may sensitize tumors to anaplastic lymphoma kinase inhibitors. Cancer Res 2008;68:3389-95.

136. Christensen JG, Zou HY, Arango ME, Li Q, Lee JH, McDonnell SR, Yamazaki S, Alton GR, Mroczkowski B, Los G. Cytoreductive antitumor activity of PF-2341066, a novel inhibitor of anaplastic lymphoma kinase and c-Met, in experimental models of anaplastic large-cell lymphoma. Mol Cancer Ther 2007;6:3314-22.

137. Choi YL, Soda M, Yamashita Y, Ueno T, Takashima J, Nakajima T, Yatabe Y, Takeuchi K, Hamada T, Haruta H, Ishikawa Y, Kimura H, Mitsudomi T, Tanio Y, Mano H. EML4-ALK mutations in lung cancer that confer resistance to ALK inhibitors. N Engl J Med 2010;363:17349.

138. Katayama R, Khan TM, Benes C, Lifshits E, Ebi H, Rivera VM, Shakespeare WC, lafrate AJ, Engelman JA, Shaw AT. Therapeutic strategies to overcome crizotinib resistance in non-small cell lung cancers harboring the fusion oncogene EML4-ALK. Proc Natl Acad Sci U S A 2011;108:7535-40.

139. Sasaki T, Koivunen J, Ogino A, Yanagita M, Nikiforow S, Zheng W, Lathan C, Marcoux JP, Du J, Okuda K, Capelletti M, Shimamura T, Ercan D, Stumpfova M, Xiao Y, Weremowicz S, Butaney M, Heon S, Wilner K, Christensen JG, Eck MJ, Wong KK, Lindeman N, Gray NS, Rodig SJ, Janne PA. A novel ALK secondary mutation and EGFR signaling cause resistance to ALK kinase inhibitors. Cancer Res 2011;71:6051-60.

140. Zhang S, Wang F, Keats J, Zhu X, Ning Y, Wardwell SD, Moran L, Mohemmad QK, Anjum R, Wang Y, Narasimhan NI, Dalgarno D, Shakespeare WC, Miret JJ, Clackson T, Rivera VM. Crizotinib-resistant mutants of EML4-ALK identified through an accelerated mutagenesis screen. Chem Biol Drug Des 2011;78:999-1005.

141. Sakamoto H, Tsukaguchi T, Hiroshima S, Kodama T, Kobayashi T, Fukami TA, Oikawa N, Tsukuda T, Ishii N, Aoki Y. CH5424802, a selective ALK inhibitor capable of blocking the resistant gatekeeper mutant. Cancer Cell 2011;19:679-90.

142. Lovly CM, Heuckmann JM, de SE, Chen H, Thomas RK, Liang C, Pao W. Insights into ALK-driven cancers revealed through development of novel ALK tyrosine kinase inhibitors. Cancer Res 2011;71:4920-31.

143. Heuckmann JM, Holzel M, Sos ML, Heynck S, Balke-Want H, Koker M, Peifer M, Weiss J, Lovly CM, Grutter C, Rauh D, Pao W, Thomas RK. ALK mutations conferring differential resistance to structurally diverse ALK inhibitors. Clin Cancer Res 2011;17:7394-401.

144. Perera SA, Li D, Shimamura T, Raso MG, Ji H, Chen L, Borgman CL, Zaghlul S, Brandstetter KA, Kubo S, Takahashi M, Chirieac LR, Padera RF, Bronson RT, Shapiro Gl, Greulich H, Meyerson M, Guertler U, Chesa PG, Solca F, Wistuba II, Wong KK. HER2YVMA drives rapid development of adenosquamous lung tumors in mice that are sensitive to BIBW2992 and rapamycin combination therapy. Proc Natl Acad Sci U S A 2009:106:474-9.

145. Bergethon K, Shaw AT, Ou SH, Katayama R, Lovly CM, McDonald NT, Massion PP, Siwak-Tapp C, Gonzalez A, Fang R, Mark EJ, Batten JM, Chen H, Wilner KD, Kwak EL, Clark JW, Carbone DP, Ji H, Engelman JA, Mino-Kenudson M, Pao W, lafrate AJ. ROS1 rearrangements define a unique molecular class of lung cancers. J Clin Oncol 2012;30:863-70.

146. Rimkunas VM, Crosby KE, Li D, Hu Y, Kelly ME, Gu TL, Mack JS, Silver MR, Zhou X, Haack H. Analysis of receptor tyrosine kinase ROS1positive tumors in non-small cell lung cancer: identification of a FIG-ROS1 fusion. Clin Cancer Res 2012;18:4449-57.

147. Paik PK, Arcila ME, Fara M, Sima CS, Miller VA, Kris MG, Ladanyi M, Riely GJ. Clinical characteristics of patients with lung adenocarcinomas harboring BRAF mutations. J Clin Oncol 2011;29:2046-51.

148. Garrido P, de CJ, Concha A, Felip E, Isla D, Lopez-Rios F, Paz-Ares L, Ramirez J, Sanz J, Gomez JJ. Guidelines for biomarker testing in advanced non-small-cell lung cancer. A national consensus of the Spanish Society of Medical Oncology (SEOM) and the Spanish Society of Pathology (SEAP). Clin Transl Oncol 2012;14:338-49. 